\title{
Math and Economics: Implementing Authentic Instruction in Grades K-5
}

\author{
Krista Althauser ${ }^{1}$, Cynthia Harter ${ }^{2}$ \\ ${ }^{1}$ Curriculum and Instruction Department, Eastern Kentucky University, Richmond, KY, USA \\ ${ }^{2}$ Economics Department, Eastern Kentucky University, Richmond, KY, USA \\ Correspondence: Krista Althauser, Curriculum and Instruction Department, Eastern Kentucky University, Richmond, \\ KY, USA
}

\author{
Received: December 21, 2015 Accepted: January 11, 2016 Online Published: January 22, 2016 \\ doi:10.11114/jets.v4i4.1328 \\ URL: http://dx.doi.org/10.11114/jets.v4i4.1328
}

\begin{abstract}
The purpose of this study is to outline a partnership program that involved a local elementary school district, an institution of higher education, the local business community, and a state economic education advocacy group to integrate economics into math in grades K-5. The "Economics: Math in Real Life" program was provided in collaboration with a Title I program to integrate economics and personal finance content into mathematics instruction to demonstrate real-life applications of math concepts and increase students' knowledge in this content area. Pretests and posttests were administered to gauge effectiveness of the authentic instruction program in increasing student knowledge in math and economics and teacher knowledge in economics. Empirical results indicate learning occurred in both math and economics for students in grades 3-5 and in economics for teachers.
\end{abstract}

Keywords: economic education, mathematics education, professional development, authentic instruction, authentic context

\section{Introduction}

A second-grade teacher who set out to teach her students a math lesson on data analysis while implementing economics ended up heading a food drive that yielded more than 3,000 items. The teacher, who had attended a math workshop that featured economics lessons for the classroom, applied an innovative concept to teach economics to her 26 students, focusing on a food drive as the culminating activity of the program. Although the food drive began as a class project to help restock the shelves of the school-based Family Resource Center, the excitement soon spread throughout other classrooms in the school.

Students in all grades became involved in the project. They sent letters to their classmates' families informing them of their plans for a week-long food drive, with each grade responsible for bringing in different items. The process developed into a friendly contest between the grades. A graph was hung on the wall in the cafeteria documenting the number of items contributed by each class. Over the course of the food drive, the graph had to be remade four times to accommodate the increasing number of items.

"It was amazing to see how involved all of the children in the school were with this project," the teacher shared. "Every day, the students came to lunch ready to check the graph and compare the numbers to see which class was leading and which one was behind. You could hear math conversations at the lunch tables as the children calculated by how many [items] one class was ahead or behind the others. Lots of mental math strategies were shared. This math/economics project was such a great success," she said. "I can't wait to do it again next year."

This one teacher introduced new ideas to the classroom by designing a math lesson that was not straight from a textbook. Incorporating economics not only motivated students to want to become involved in mathematics, but also enabled those students to discover and express their interest in math and economics. The resulting contagious enthusiasm was a welcome phenomenon not encountered in most schools.

Math in the classroom has a tendency to trigger sentiments of dislike, indifference, and failure. All educators should be concerned about why students and adults are so comfortable discussing their failures in mathematics. Examining this issue might well be a key to solving the problem of student achievement in mathematics. In the classroom scenario, a resourceful teacher brought a topic to her students that created genuine interest and enthusiasm. That interest and enthusiasm promoted student achievement in mathematics, not dislike or failure. 


\subsection{Making Math Meaningful}

Teaching content that is both significant and worthwhile makes math enjoyable and meaningful for students (Weiss \& Pasley, 2004), but teaching significant content is not enough. Mathematics education must engage students in ways that invite students to interact purposefully with the content to make the learning personally and socially meaningful. Seeing mathematics in the real world and recognizing its power to investigate critically and influence real-world situations are key components of critical perspectives on teaching and learning mathematics (Gutiérrez, 2007; Gutstein, 2003, 2006, 2007; Skovsmose, 1994).

According to Diez-Palomar, Simic, \& Varley, (2007) effective lessons that represent mathematics as a dynamic body of knowledge, generated and enriched by investigation to guide students in developing a real-world connection, are the most conducive to student achievement. Engaging students with the mathematics content, creating an environment conducive to learning, ensuring access for all students, using questions to monitor and promote understanding, and helping students to make sense of the mathematics content are key factors of effective lessons (Weiss, Pasley, Smith, Banilower, \& Heck, 2003; Gutstein, 2007). A teacher's success in delivering effective lessons determines students' opportunities to learn. Learning opportunities must engage students in doing the intellectual work and making sense of the key concepts being addressed. The teacher's role in these learning opportunities is to guide students and provide help to ensure students are making real-world connections, such as the real-world connection discussed in the research conducted by Civil \& Khan (2001).

School mathematics lessons are typically disconnected from students' lives (Chazan, 2000; Moll \& Ruiz, 2002; Tate, 1995; Valenzuela, 1999). Largely abstract and decontextualized curricula provide little indication of how students will benefit from the mathematics that is taught (Martin, 2000), whereas "Piaget's theory . . . states, in essence, that logico-mathematical knowledge, including number and arithmetic, is constructed (created) by each child from within, through interaction with the environment" (Kamii, 2000, p. 3). More recently, researchers have applied critical perspectives on teaching and learning to mathematics education by implementing authentic contexts that involve interaction with real-world situations to guide the child into making necessary connections (Allsopp, Kyger, \& Lovin, 2007; Hill, Schilling \& Ball, 2004).

\subsection{Authentic Contexts}

Learning outcomes are enhanced for all learners when instruction is anchored in rich and meaningful contexts and relevance to the real world can be perceived (Bottge, 1999; Bottge, Heinrichs, Chan, Mehta, \& Serlin, 2001). When mathematical concepts are introduced in authentic contexts that help students make real-world connections, students are more likely to (a) see value in learning the mathematical concept, (b) have greater capacity to remember what they have learned, and (c) be more likely to have cognitive access to the meaning of the concept (Allsopp et al., 2007).

Although the manner in which authentic contexts are created can vary greatly, Allsopp et al. (2007) suggested four components that should be incorporated when teaching. First, the context must be age-appropriate/relevant; both students' cognitive/mental age as well as their chronological age should be considered. Second, the context of the instruction must be culturally responsive. The context should resonate with students' language, family, and community experiences. Third, the context must be of interest to students. Fourth, the concept must be depicted clearly through the context, not hidden by the content.

The purpose of building meaningful connections is to assist students in making important connections between what they already know and what they will learn in the new instructional lesson or instructional activity. Students whose previous knowledge is activated are more likely to be able to make full use of their cognitive processing abilities because they are thinking about the kinds of ideas that will help them the most (Allsopp et al., 2007). In traditional teaching, students sit at their desks and watch their teacher explain math problems and techniques on the board; traditional teaching does not promote learning for most students (Husain, Cahill, \& Lozada, 1999). Instead, students need to apply the math content meaningfully by solving real-world problems from their own lives as described by Vadeboncoeur (2006).

Many learners have difficulty with memory, attention, and metacognition, which can interfere with the ability to relate and connect concepts to each other. To ensure optimal learning, teachers must plan and then teach explicitly how what is being taught links to students' previous knowledge and experiences. Using this instructional practice in combination with teaching in authentic contexts can provide a very powerful instructional foundation for teaching any mathematical concept to all students (Allsopp et al., 2007).

When teachers, students, or parents are asked about what students should be learning in school, their answer usually includes a belief about school being meaningful and relevant to the real world (Dennis \& O'Hair, 2010). All too often, meaningful, in-depth understanding and applications to the world beyond school are not being used to teach 
mathematics content - the essence of using authentic instruction. Instead, student learning is often based on traditional applications such as rote memorization of useless facts, skills taught in isolation, or meaningless procedures that have no value outside of school (Battista, 1999). Math lessons need to be designed and executed to show students that math is everywhere. Teachers need not rely solely on textbooks and paper homework to teach the skills. Students learn better and retain more when math subjects are applied to relevant, hands-on situations (Husain et al., 1999).

Authentic instruction is an essential component in the design of meaningful and relevant math lessons. Meaningful, relevant lessons are taught at a higher intellectual level and contain information and skills that are of value beyond school to bolster student achievement (Allsopp et al., 2007). As part of these higher level lessons, students are asked to analyze, synthesize, and evaluate information, such as solving a math problem, drawing conclusions about how they solved it, and then predicting multiple ways to solve the problem. Savvy teachers encourage arguments among students about which method is the best and makes more sense to students. Authentic instruction goes a step further than traditional teaching, asking students to apply the math skill to a real-world situation in their lives (Carpenter, Fennema, Peterson, Chang, \& Loef, 1989).

Three criteria link authentic instruction to student achievement: construction of knowledge, disciplined inquiry, and learning that is of value beyond school (Allsopp et al., 2007). For some teachers, implementing authentic instruction criteria in the classroom is challenging, especially for those wedded to using traditional approaches. These teachers will need to change radically their instructional strategies and teaching practices in the classroom. Higher order thinking skills and connecting "outside" material to the classroom have been noted as two of the most difficult components to incorporate into authentic instruction (D'Agostino, 1996). Instruction that emphasizes meaning and understanding is demanding on teachers, and not all teachers are willing to take the initiative to use these practices (Ball, 1996; Loucks-Horsley, Love, Stiles, Mundry, \& Hewson, 2003).

Numerous studies (Fouts, Baker, Riley, Abbott, \& Robinson, 2001; Huffman \& Hipp, 2003; Starratt, 2004) have shown the effectiveness of authentic instruction criteria in improving student achievement. Skovsmose $(1994,2000)$ argued that students should be prepared to use mathematics as a tool to understand critically, investigate, and act on their world, a capacity that authentic instruction promotes. Many researchers adamantly support the notion that education grounded in students' experiences, needs, and circumstances has the potential to be transformative (González, Andrade, Civil, Moll, 2001; Skovsmose \& Valero, 2002; Valenzuela, 2002; Civil, 2002). Students who perceive their out-of-school experiences are valued and make connections been these events and their mathematics content have greater potential to appreciate the relevance of school, better positioning them to see mathematics, in particular, as a powerful tool in their lives (Turner \& Strawhun, 2007).

One way to utilize authentic instruction in the classroom is to integrate real-world content and events in the teaching of mathematics. Abel and Abel (1996) provide examples of ways teachers can integrate math and social studies in a meaningful way which allows students to "construct their own knowledge based on their interaction with peers, teachers, and the internet" (p. 1). They use the internet and integrated learning to simulate real world problems for students to address. They also present Beane's (1993) description that integrated learning is about "unifying deeply meaningful experiences in learning for students, not about following a prescribed plan. It's teaching which draws out and brings forth capacity for children to be lifelong learners" (p. 2). As described by Braunger and Hart-Landsberg, 1994, "teachers are recognizing the unity of knowledge with creative approaches based on activities, projects, and inquiry-led instruction" (p. 2). The collaborative "Economics: Math in Real Life" project we provided led teachers to use these approaches and integrate economics into the teaching of math.

\subsection{Improving Mathematics Education by Implementing Economics}

Economic concepts can be readily connected to mathematics content and taught in the elementary grades. The key is to focus on classroom events that relate to economic concepts. Since economics is the study of decision making due to scarcity, this is easy to do. Even young students experience scarcity and make decisions every day. Presenting economic ideas to young children can be challenging for some teachers, but young people can learn simple ideas of economics and personal finance when those concepts are presented in an engaging and well-organized way (Posnanski, Schug, \& Schmitt, 2007).

The teacher who is knowledgeable about basic economic concepts can integrate the concepts that are either directly or indirectly relevant to mathematics to help students see the relevance of both economics and math to their lives. Rather than learning mathematics content in and only for itself, integration of economics provides a rich context for students to connect mathematics to real-life situations. Most opportunities to learn about economics in real-life context occur beyond the classroom, so making connections between math lessons and economics content is crucial for young learners (Meszaros \& Evans, 2010).

Too often, what is learned and practiced in one content area fails to carry over into another. Authentic instruction 
supports using knowledge or skills acquired in one context in a new or varied context (Allsopp et al., 2007). Integrating economics teaching with math content presents young children with opportunities for better understanding of financial information. For example, elementary school teachers can teach about money in math class, and this can lead to discussions about saving, spending, and (in the upper grades) how interest works. The economic concept of interest can be used to reinforce computation skills to determine costs of production, unit cost, and accounting profit and loss. Presenting economics with connections to the rest of the curriculum boosts higher order thinking skills that, when blended with the study of mathematics and economics, yields knowledge applicable in the world beyond the classroom (Posnanski et al., 2007). This transfer of knowledge and skill is critical if we want students to apply classroom learning to their everyday lives.

Walstad (1979) used a two-stage least-squares approach to investigate the use of a particular teacher in-service program (the Unified Science and Mathematics for Elementary School curriculum) and concluded that intermediate elementary students "appear to improve their economic understanding significantly by working on comprehensive, realistic, and economics-oriented problems" (p. 9). Georgiou (2003) showed that integrating economics into the social studies curriculum improved economics outcomes on state assessments, while Walstad and Watts (1985) cautioned that although infusion or integration is a commonly used approach for teaching economics in the elementary grades, time limitations prevent teaching more of the content. If economics can be integrated into mathematics in the elementary school setting, perhaps learning can improve in both areas of content. Terminology, understanding, and attitudes developed at an early age "serve as a springboard for more effective learning and mastery in later schooling and life" (Hansen, 1985, p. 219), possibly supporting improved attitudes toward both math and economics. Young students have the potential to learn the economics content; whether or not that learning occurs depends on demand by the school district, materials, time, teacher effectiveness, and evaluation of efforts. The program, "Economics: Math in Real Life," addresses each of these determinants.

\section{Method}

Two hundred three elementary (K-5) school teachers from one county in the southeastern United States and employed in one of 10 schools, participated in a professional development program. These elementary teachers taught different grade levels and all were full-time certified regular teachers who teach mathematics in collaborative classrooms. All 10 schools consisted of kindergarten through fifth grade, and all of the teachers participated in a job-embedded, economics professional development program two times a year over a one-year period.

Teachers who participated in the professional development program completed the Test of Economic Knowledge (Walstad and Soper, 1987) as a pretest and a posttest. This 39-question, multiple-choice test is commonly used to measure economics knowledge for students in grades 7-9, and this was a reasonable assessment instrument for our teachers of elementary grades who may or may not have taken economics in high school or college. Students in grades 3-5 were administered the 29-question, multiple-choice Basic Economics Test (Chizmar \& Halinski, 1981) which focuses on economics knowledge for upper-elementary grades as well as the Trends in International Mathematics and Science Study (TIMSS) elementary math test which consists of 25 multiple-choice questions covering the five math content areas. Students in grades K-2 pretested and posttested using the 15-question Economics for Primary Grades Test (Morgan, 1991). These instruments were designed to assess general knowledge about economics and math concepts for various grade levels and are widely used in research studies.

\subsection{Program Overview}

This program combined financial support from partners with collaboration from teachers. We provided elementary teachers with various economics and personal finance curricula to review during spring, 2009, and the teachers cooperatively chose the curricula they thought would be most useful for their particular grade levels. This process of allowing the teachers to choose their own materials could increase the likelihood the teachers might continue to use the materials for years to come. From these materials, we extracted lessons with math content and trained the teachers in those lessons; in particular, we showed the teachers how they could integrate math into children's literature, personal finance, economics, and other content areas. The technology coordinator of the local district presented technology applications of the curricula to help teachers extend coverage and integration. In some cases, we supplemented materials with additional, relevant math activities to ensure each lesson contained specific math applications.

We aligned lessons to national standards in economics and mathematics. These alignment charts formed the basis for implementation plans we constructed for the teachers to indicate which lessons to cover from the various curriculum materials to teach grade-level-specific math concepts integrated into other subject areas. For example, we provided teachers with the know-how to integrate personal finance and math content into their existing classes, and we prepared all of the materials for teachers to use when they applied the implementation plan in their classrooms, enabling them to use their newfound skills right away. We gave each teacher a resource bag that contained materials, such as 
manipulatives (e.g., money sets and laminated game pieces), children's literature books, classroom signs, and supplies needed to teach the lessons. Each teacher also received a free copy of the curriculum from which they were instructed to teach.

To introduce the program to teachers, we planned six full-day workshops to take place at the beginning of the school year (in September) and follow-up training halfway through the school year (in January), during which we trained the teachers in the chosen curricula. These workshops were district-supported and were held at a local elementary school. All of the math and social studies elementary teachers (grades K-5) from the district, as well as special education teachers, were required to attend their grade-level-specific workshop. Careful planning allowed us to incorporate this program into the existing math intervention program sponsored by Title I.

The September and January workshop agendas were similar and included 30 minutes for pretesting or posttesting, along with three 100-minute training sessions and breaks between the sessions. Two of the sessions focused explicitly on lessons from the chosen curriculum, with particular attention to lessons that include math content, while the third lesson focused on lessons from the curricula that involved technology applications and also on student testing procedures using technology provided by the district.

Along with the implementation plan we gave each teacher, we also provided materials for the teachers to pretest and posttest their students. Teachers were instructed to use district technology to test the students online. Teachers in grades 3-5 were provided with the Basic Economics Test to pretest and posttest their students using an electronic, multiple-choice test format. Teachers in grades K-2 used the Economics for Primary Grades test developed by Morgan (1991), a 15-question Yes/No assessment that could be administered orally using the clicker system, for pretesting and posttesting their students.

Curriculum materials we presented for each grade level are identified in Table 1. Teachers of grades 4 and 5 chose the same materials, requesting vertical integration between the two grade levels. To satisfy the Grade 4 and Grade 5 teachers, we chose different lessons from the same materials.

Table 1. Grade-Level Curriculum Materials

\begin{tabular}{ll}
\hline Grade & Curriculum \\
\hline K & Gingerbread Man Economics \\
1 & K Thru 2 Can Do! Math \& Economics \\
2 & Pint-Size Economics for K-2 (with Kids Econ Posters Set A) \\
3 & Spotting Economics: From Africa to Ice Cream \\
4 & Mathematics and Economics - 4th \\
& Teaching Economics Using Children's Literature - 4th \\
5 & Mathematics and Economics - 5th \\
& Teaching Economics Using Children's Literature - 5th \\
\hline
\end{tabular}

The Test of Economic Knowledge was administered to teacher participants at the beginning of the September workshop as a pretest and again at the end of the January workshop as a posttest. At the mid-year follow-up workshops, we debriefed the teachers about their experiences with the lessons and supplemented the training with additional lessons, games, and resources. We collected information about student test results at that time, too. We discovered many of the teachers had not yet completed the testing due to issues related to technology, weather, illness, or other unforeseen complications, so collection of student testing data continued throughout the spring semester.

The second set of six full-day workshops in January focused more specifically on integrating personal finance into math content. We trained the teachers in using additional lessons from the curricula distributed in September, presented activities from various resources (including the Council on Economic Education's Virtual Economics 3.0 CD-ROM, econedlink.com, and What Economics is About, grade-specific personal finance games developed by Bonnie Meszaros of the University of Delaware, Federal Reserve Board resources, and the Kentucky Council on Economic Education's KCEE's Favorite Books for teaching elementary students), and spent time discussing strengths and weaknesses of integrating math into economics and conducting student testing.

\section{Empirical Results}

As shown in Table 2, averages of teachers' posttest scores (73\%) on the Test of Economic Knowledge were higher than those for pretest scores $(66.59 \%)$ for every K-5 grade level, which suggests the program did increase teachers' knowledge of economics. The question, then, was whether teachers' increased knowledge translated to their students. 
Table 2. Teacher Pretest and Posttest Economics Averages

\begin{tabular}{lcc}
\hline Grade taught & Average pretest $\%(n)$ & Average posttest $\%(n)$ \\
\hline Kindergarten & $59.16 \%(n=32)$ & $61.75 \%(n=21)$ \\
1st & $64.66 \%(n=50)$ & $68.33 \%(n=43)$ \\
2nd & $69.36 \%(n=50)$ & $76.00 \%(n=48)$ \\
3rd & $68.09 \%(n=43)$ & $70.95 \%(n=39)$ \\
4th & $67.81 \%(n=26)$ & $79.13 \%(n=31)$ \\
5th & $70.61 \%(n=23)$ & $79.18 \%(n=28)$ \\
Consolidated & $66.59 \%(n=223)$ & $73.00 \%(n=209)$ \\
\hline
\end{tabular}

All student data were scrubbed of identifying information before we analyzed test data. Although student completion rates (that is, the combined pretest and posttest scores) were somewhat lower than expected, the results obtained are compelling. For grades 2 through 5 as a whole, posttest averages on the economics tests were higher than pretest averages. The improvement was statistically significant for grades 4 and 5. Students in grades 3 through 5 also took math pretests and posttests, and scores indicated statistically significant improvements in math performance in all of those grades. Students did learn economics and math, so the program accomplished its primary goal. By using authentic instruction to teach math in the context of applications to real-world economics and personal finance content, perhaps we have promoted longer term learning in math and helped bridge students' gaps in comprehending the relevance of math to the real world.

\subsection{Student Results for Grades 3-5}

Students in grades 3-5 took the Basic Economics Test using the electronic Turning Point testing system provided by the school district. All 29 test questions were multiple-choice, and this nationally normed test is geared toward the upper elementary level, meaning that if a random sample of upper elementary students took the test, the average score should be 50\%. The results would be expected to fit a bell-shaped curve. Teachers do not typically use this type of test to gauge student learning in the classroom where tests are geared more directly to specific coursework. Despite its shortcomings for use in practical settings of the average classroom, the test is good for measuring student learning from a research perspective because it is statistically reliable and valid. Results obtained from testing students using the Basic Economics Test are acceptable in the academic arena and meet rigorous criteria.

We received individual students' test scores for grades 3-5 and averaged them. As shown in Table 3, the posttest average scores were higher than the pretest averages for every grade. The students performed better in terms of knowledge of economics after their teachers taught lessons integrating economics into math content. We were not able to match pretest and posttest scores for all of the students because some took one and not the other. Therefore, we computed a $z$-test statistic to compare the two mean values for each grade. That is, we compared the posttest and pretest averages for each grade level to determine whether the improvement was statistically significant (see Table 3). For the improvement from pretest to posttest to be statistically significant at a .025 significance level, the $z$ statistic must be greater than 1.96. Statistical significance is important because, if a result is statistically significant, then we can say the increase in test scores is unlikely to have occurred by chance. It is evident from the results presented in Table 3 , that the improvement is statistically significant for grades 4 and 5 but not for Grade 3 . Third graders did improve their average score, but it was not enough to be statistically significant.

Table 3. Student Basic Economics Test Results, Grades 3-5

\begin{tabular}{|c|c|c|c|c|c|c|}
\hline Grade & Teachers $(N)$ & Students $(N)$ & $\begin{array}{l}\text { Students' } \\
\text { averages }\end{array}$ & pretest & $\begin{array}{l}\text { Students' posttest } \\
\text { averages }\end{array}$ & $\begin{array}{l}z \\
\text { comparison, } \\
\text { pre-/posttest }\end{array}$ \\
\hline 3 & 36 & 586 & $31.37 \%$ & & $32.90 \%$ & 1.76 \\
\hline 4 & 25 & 542 & $40.73 \%$ & & $48.30 \%$ & 5.93 \\
\hline 5 & 26 & 582 & $55.13 \%$ & & $64.71 \%$ & 7.65 \\
\hline
\end{tabular}

Students in grades 3-5 took the TIMSS math test using the electronic Turning Point system provided by the school. The 25 questions on the TIMSS are all multiple-choice, and the test covers the following mathematics topics: whole numbers; fractions and proportionality; measurement, estimation, and number sense; data representation, analysis, and probability; and geometry, patterns, relations, and functions. We received individual students' TIMSS test scores for grades 3-5 and averaged them. As shown in Table 4, the posttest average is higher than the pretest average for every grade. The students performed better in terms of knowledge of mathematics after their teachers taught lessons integrating economics into math content. Again, we conducted a $z$-test of the difference of means to compare the posttest average and pretest average for each grade level (see Table 4). The gains in student performance in math are statistically significant for all of grades 3,4 , and 5 . 
Table 4. Students' TIMSS Test Results, Grades 3-5

\begin{tabular}{lccccc}
\hline & & & & \multicolumn{2}{c}{$\begin{array}{l}z \\
\text { statistical } \\
\text { comparison, } \\
\text { pre-/posttest }\end{array}$} \\
\hline 3 & Teachers $(N)$ & Students $(N)$ & $\begin{array}{l}\text { Students' } \\
\text { averages }\end{array}$ & pretest & $\begin{array}{l}\text { Students' posttest } \\
\text { averages }\end{array}$ \\
4 & 34 & 556 & $31.68 \%$ & $35.74 \%$ & 4.19 \\
5 & 27 & 580 & $44.34 \%$ & $56.24 \%$ & 5.80 \\
\hline
\end{tabular}

Next, we combined the results from the student testing in grades 3-5 with demographic information for those students in order to perform regression analysis to investigate whether student demographics affected their test scores. Demographic data included grade level, gender, and whether the student was eligible to receive free or reduced-price lunch, and regression analysis allows us to analyze the relationship between the dependent variable and these independent variables. As shown in Table 5, we regressed the posttest score for the economics test on the demographic variables and also the pretest math score (which is often used as a proxy for academic ability in these kinds of studies).

Table 5. OLS Regression Results, Grades 3-5 (Dependent Variable = EconPost)

\begin{tabular}{lrrr}
\hline Demographic & Coefficient & $t$ & \multicolumn{2}{l}{} \\
\hline Grade 5 & 11.463 & 11.03 & 0.000 \\
Female & 1.290 & 1.43 & 0.152 \\
Free lunch & -1.896 & -2.04 & 0.041 \\
Math pretest & 0.527 & 23.22 & 0.000 \\
Constant & 20.629 & 16.82 & 0.000 \\
\hline
\end{tabular}

Note. $N=1,734$. Adjusted $R^{2}=0.39$.

In Table 5, the $t$-statistic, the coefficient divided by its standard error, allows us to evaluate the hypotheses that each of the independent variables has no effect on student posttest scores. The p-value tells us the probability of observing a $\mathrm{t}$-statistic as large as the one we obtained if the independent variable does not impact posttest score. Therefore, a low t-statistic corresponds to a high p-value, and this result would mean that the variable likely has little impact on posttest scores. From these results, being in fifth grade - as opposed to third or fourth grade — is a statistically significant positive predictor of economics posttest score, as is student score on the math pretest. Gender is not a significant predictor while income level, as denoted by eligibility for the free or reduced-price lunch, is a negative predictor. Thus, receiving free lunch is a negative and significant predictor of test score.

As indicated in Table 6, we used the math posttest score as the dependent variable with the same independent variables, except that we substituted the pretest score on the economics test for the pretest score on the math test. These results are very similar to those in Table 5. Being an older student and doing better on the economics pretest are significant predictors of posttest score in math, and free lunch is a negative predictor. Again, gender is not significant at the elementary level.

Table 6. OLS Regression Results, Grades 3-5 (Dependent Variable = MathPost)

\begin{tabular}{|c|c|c|c|}
\hline Variable & Coefficient & $t$ & $p$ \\
\hline Grade 5 & 7.746 & 6.71 & 0.000 \\
\hline Female & -0.868 & -0.89 & 0.375 \\
\hline Free lunch & -4.906 & -4.87 & 0.000 \\
\hline Econ pretest & 0.585 & 22.04 & 0.000 \\
\hline Constant & 27.800 & 21.31 & 0.000 \\
\hline
\end{tabular}

Note. $N=1,615$. Adjusted $R^{2}=0.35$.

\subsection{Student Results for Grades $K-2$}

Students in grades K-2 were administered the 15-question Economics for Primary Grades test using an audience-response, clicker system, which facilitates testing a class that includes nonreaders. The test questions were displayed on a screen and read aloud, and the students selected "Yes" or "No" using a clicker. This test is not a nationally normed test, but it has been used in academic publications to measure economics learning in early grades (Morgan, 1991). The results that were provided to us for analysis were class averages for each question. In other words, we received a report from each class indicating the percentage of students who answered "Yes" and the percentage who answered "No" for each question. We did not receive data on individual student responses for these grades. Because so few classes completed the testing and the level of observation is the class and not the individual student, statistical analysis was difficult to perform. Also, students in these grades did not take a math test as part of this program.

It is generally acknowledged that testing students in these early grades is problematic because "the mechanics of taking tests can prove more difficult than the cognitive tasks the tests are asking them to address" (Engel, 2007, p. 1). Furthermore, some young students may find standardized tests scary. To minimize any problems with testing these 
young students, we limited testing for the purposes of this program to only 15 questions and administered the questions in a group setting. Despite this, we view our results with caution in terms of drawing meaningful conclusions because of the students' young ages and the small number of classes that actually completed the testing.

The posttest average shown in Table 7 is higher than the pretest average for second grade. We did not conduct statistical analyses on the scores due to the small number of classes that completed the testing in these grades and the difficulty in testing students in these early grades. Also, some of the teachers had trouble with the testing equipment due to inexperience, technical issues, and scheduling problems. Determining meaningful statistical results with such small numbers is problematic, and any conclusions drawn from the results should be viewed with caution.

Table 7. Student Test Results, Grades K-2

\begin{tabular}{lllll}
\hline Grade & Teachers $(n)$ & Students $(n)$ & $\begin{array}{l}\text { Students' } \\
\text { averages }\end{array}$ & $\begin{array}{c}\text { pretest } \\
\text { Students' posttest } \\
\text { averages }\end{array}$ \\
\hline $\mathrm{K}$ & 3 & N/A & $49.50 \%$ & $46.95 \%$ \\
1 & 10 & N/A & $50.81 \%$ & $49.31 \%$ \\
2 & 15 & N/A & $52.54 \%$ & $56.01 \%$ \\
\hline
\end{tabular}

\subsection{Teacher Feedback}

In the January workshops, we solicited teachers' feedback about their experiences in this program. When we asked the teachers whether, based on their experiences in this project, it made sense to integrate economics into math, $100 \%$ of the teachers who answered the question said, "Yes." Several added that it provided useful and interesting real-world applications of the math concepts. We consolidated and summarized the teachers' comments as follows.

In response to the question, "Please describe the strengths of using these lessons in your classes," many teachers mentioned that the students liked the hands-on activities and had fun with the activities. The teachers liked the materials, especially the well-planned lessons and supplements such as the literature books and manipulatives. According to the teachers, students were able to make real-world connections and apply what was taught in class to their own lives outside of the classroom. The literature accompanying the lessons was remarked to have helped engage the students in the content, including those students who had previously not paid much attention, so the teachers believed more learning occurred. Teachers also remarked that the activities helped children learn important vocabulary, and the children enjoyed investigating as part of the interactive lessons. Doing something different during math time was a welcome change, and the lessons were developmentally appropriate and provided a fun, interesting way to discuss and learn about this content with young students. Teachers appreciated the integration of lessons and technology, although some teachers perceived the technology to be a double-edged sword.

Teachers' comments indicated they appreciated the program for what it brought to the students. The program introduced students to economics in ways that they could relate to and they came out with a better understanding of how money and the economy work. The lessons helped students develop strong reasoning skills and were a fun, useful approach to teaching what can be a difficult-to-teach subject. Having materials and supplements provided to them gave the teachers more time to prepare and teach. Students involved their parents in some of the lessons, which was a change of pace, and they were able to make connections to literature and real-world situations. Students were engaged and felt comfortable in discussing items that they knew about, such as money, and they shared because they knew the real-world relevance of the content. Because the lessons were hands-on and student-friendly, students who normally would not be very involved in class showed excitement. As one teacher relayed, one student in particular remarked, "This is kinda fun . . . and challenging at the same time." Perhaps best of all, teachers reported that students remembered the material better because of the activities and stories.

In response to the question, "Please describe the weaknesses of using these lessons in your classes," many teachers said they needed more time because some of the lessons were lengthy. The testing technology was deemed by some teachers to be problematic, either because the teachers were not familiar with how to use it or it did not work well when a whole class of students tried to take tests at the same time. Teachers wanted more copies of the books they were given, as well as copies of the books that were covered in curriculum lessons that were not included as part of this project. Some teachers said that preparatory activities were needed to bring their students up to a level of knowledge required for the lessons they were expected to teach. However, as the program is implemented over time, it would be expected that students would have the appropriate knowledge base for each grade level.

Teachers requested more connection to their curriculum map for these lessons and some expressed concern about not having enough time to work the lessons into their existing plans. This was a particularly significant problem for Kindergarten teachers who have only half-day classes. Some teachers struggled with a lack of connection, while others appreciated that there was plenty of material for them to choose from and modify to include as they chose. Each grade was given a set of lessons from which to pick and choose which would work best in their specific classrooms, so it is unclear, 
particularly within the same grade, why some teachers wanted more choice and others had no complaints. Some said the program was difficult to incorporate during the first year, but they would be better able to work the program into existing plans in the future. Some of the lower grade-level teachers reported that some of the content was inappropriate for their students, especially regarding the vocabulary. Again, the program requires repeated review throughout elementary grades so that students will know the vocabulary and have the knowledge base needed as they get older. Almost all of the teachers suggested teaching economics throughout all grades levels and some requested putting economics on the curriculum map with math to aid in integration. Many teachers believed the wording on the tests was not grade-appropriate, and some lower grade-level teachers reported that using the clickers was difficult for their students. This process should improve as the teachers and students gain more familiarity with the equipment.

When asked about the usefulness of pretesting and posttesting their students, most of the upper level teachers reported that it was helpful to see what gains in learning took place while teachers in the lower grades struggled with the tests and were not so clear on the usefulness of these tests. Because of the integration of testing with technology, this question elicited comments about problems with using the technology, which several teachers found frustrating and difficult to use. Several teachers commented that the actual tests given were not useful because they did not specifically cover material from the assigned lessons, and other teachers said they did not understand why they had to do the tests. These comments are not too surprising because the testing done in this program is different from traditional testing. The tests were selected from a set of research tests that are designed to measure general knowledge about particular content areas so they are intentionally not tied to any particular curriculum. They are constructed in a way that makes it difficult to "teach to the test" so that the tests will more accurately measure a gain in overall content knowledge. This approach is best for evaluating the overall effectiveness of a training program.

When we asked the teachers what would make it easier to continue this program in the classroom, many teachers suggested field trips to community sites, such as a bank, factory, or grocery store, or more manipulatives such as piggy banks. Most of the teachers suggested more time to cover lessons and more time for planning and implementing the program, especially time with teachers in the same grade so the teachers could collaborate and plan together. Teachers requested that outside speakers come into the classroom and requested more activities for children to do with their parents outside of school. Other suggestions included CDs or tapes of books to use in listening centers, continued contact with presenters and funders, and continued training and support. Teachers wanted more exposure to economics and finance workshops, especially more professional development workshops during the school year. There was general agreement that more resources, especially children's literature books for the classroom and library, were desired.

We also asked teachers to describe some of the experiences that occurred in their classrooms. One teacher mentioned having difficulty getting students to understand the concept of scarcity until she played a game of musical chairs, after which she explained that having too few chairs for the students was an example of scarcity. She said the students were then able to grasp the concept. A second-grade teacher shared how she integrated the lessons with a program involving a student trip to a pet store to investigate the issue of buying a classroom pet. Details about the project were covered in the local newspaper. As described earlier, another second-grade teacher tied the lessons to a food drive, and her efforts were also featured in an article in the local paper. A group of third-grade teachers tied their lessons to the development of a "candygram" business that was also highlighted in the local paper. This training program impacted not only students and teachers but the wider community as well.

\section{Conclusion}

This program trained teachers to implement authentic instruction in mathematics by integrating real-world economics into the curriculum. Authentic instruction combined with curriculum alignment across disciplines and integration throughout the district are important characteristics that contributed to the overall success of the program. The effectiveness of this teacher education program is documented through a variety of measures. First, the statistical results confirm student and teacher learning. Teachers performed better on economics posttests than they had on pretests. Also, students in grades 2 through 5 performed better on economics posttests after teachers taught the relevant lessons than they had on economics pretests, and students in grades 3 through 5 performed better on math posttests after the lessons were taught than they had on math pretests. In summary, the teachers learned economics, and students learned both economics and math. Second, there was a combination of grant, district, state, and community support. Because of the partnerships, we were able to provide teachers not only with training, but also with a superb set of curriculum and materials. These materials were meant to be kept in the classroom to be used for the math and economics lessons as well as other lessons and activities in the future. Third, there are documented impacts on the local community. Several teachers tied these lessons to business ventures and community projects that took the students out of the classroom and involved them in actual applications of the content to their own lives.

Since teachers who participated in the "Economics: Math in Real Life" program improved their performances on 
economics tests from the beginning of the training to the end, we expect that this increase in teachers' knowledge will translate into more comfort and confidence with the content and more teaching of the content in the classroom. Feedback from teachers showed that the program was positive for students and garnered community support. It is important to continue the effort now that we know that the program is successful. In the longer term, we expect teachers will integrate more economics and personal finance content into their classes as an application of math content. This process will require continued support of our partners and integration of this program with newly adopted educational standards. Ultimately, we should graduate students who have a solid foundation of real-world mathematical and decision-making skills as they are exposed to this content from year to year. Such skills will benefit society at large as our students become productive and informed adults who make wise consumer decisions.

\section{References}

Abel, F. J., \& Abel, J. P. (1996). Integrating mathematics and social studies: Activities based on Internet resources. Working paper presented at the annual meeting of the Montana Council of Teachers of Mathematics, Helena, MT.

Allsopp, D. H., Kyger, M. M., \& Lovin, L. H. (2007). Teaching mathematics meaningfully: Solutions for reaching struggling learners. Baltimore, MD: Brookes.

Ball, D. L. (1996). Teacher learning and the mathematics reforms: What do we think we know and what do we need to learn? Phi Beta Kappan, 77, 500-508. Retrieved from http://ww.kappanmagazine.org

Battista, M. T. (1999). The mathematical miseducation of America's youth: Ignoring research and scientific study in education. Phi Delta Kappan, 80, 424-433. Retrieved from http://www.kappanmagazine.org/

Beane, J. A. (1993). Problems and possibilities for an integrative curriculum. Middle School Journal, 25(1), 18-23. http://dx.doi.org/10.1080/00940771.1993.11495181

Bottge, B. A. (1999). Effect of contextualized math instruction on problem solving of average and below-average achieving students. Journal of Special Education, 33, 81-92. http://dx.doi.org/10.1177/002246699903300202

Bottge, B. A., Heinrichs, M., Chan, S. Y., Mehta, Z. D., \& Serlin, R. C. (2001). Anchoring adolescents' understanding of math concepts in rich problem-solving environments. Remedial and Special Education, 22, 299-314. http://dx.doi.org/10.1177/074193250102200505

Braunger, J., \& Hart-Landsberg, S. (1994). Crossing boundaries: Explorations in integrative curriculum. Portland, OR: Northwest Regional Educational Laboratory.

Buxton, C. A. (2006). Creating contextually authentic science in a "low-performing" urban elementary school. Journal of Research in Science Teaching, 43, 695-721. http://dx.doi.org/10.1002/tea.20105

Carpenter, T. P., Fennema, E., Peterson, P. L., Chang, C. P., \& Loef, M. (1989). Using knowledge of children's mathematical thinking in classroom teaching: An experimental study. American Educational Research Journal, 26, 499-531. http://dx.doi.org/10.3102/00028312026004499

Chazan, D. (2000). Beyond formulas in mathematics and teaching: Dynamics of the high school algebra classroom. New York, NY: Teachers College Press.

Chizmar, J. F., \& Halinski, R. S. (1981). Basic Economics Test: Examiner's Manual, New York: Joint Council on Economic Education.

Civil, M. (2002). Culture and mathematics: A community approach. Journal of Intercultural Studies, 23, 133-148. http://dx.doi.org/10.1080/07256860220151050A

Civil, M., \& Khan, L. H. (2001). Mathematics instruction developed from a garden theme. Teaching Children Mathematics, 7, 400-420. Retrieved from http://www.nctm.org/publications/toc.aspx?jrnl=tcm

D’Agostino, J. V. (1996). Authentic instruction and academic achievement in compensatory education classrooms. Studies in Educational Evaluation, 22, 139-155. http://dx.doi.org/10.1016/0191-491X(96)00008-9

Dennis, J., \& O'Hair, M. J. (2010). Overcoming obstacles in using authentic instruction: A comparative case study of high school math \& science teachers. American Secondary Education, 38(2), 4-22. http://www1.ashland.edu/coe/about-college/american-secondary-education-journal

Díez-Palomar, J., Simic, K., \& Varley, M. (2007). "Math is everywhere”: Connecting mathematics to students' lives. Journal of Mathematics and Culture, 1(2), 20-36. http://nasgem.rpi.edu/pl/journal-mathematics-culture-s37

Engel, B. S. (2007). Second grade testing: A position paper. Retrieved from http://www.fairtest.org

Fouts, J. T., Baker, D. B., Riley, S. C., Abbott, M. L., \& Robinson, H. L. (2001). The Bill and Melinda Gates Foundation's model school initiative; Year 1 evaluation results. Seattle, WA: The Bill \& Melinda Gates 
Foundation.

Georgiou, G. C. (2003). Integrating economics in the K-12 curriculum. International Business \& Economics Research Journal, 2(6), 1-14. http://journals.cluteonline.com/index.php/IBER/index

González, N., Andrade, R., Civil, M., \& Moll, L. C. (2001). Bridging funds of distributed knowledge: Creating zones of practices in mathematics. Journal of Students Placed at Risk, 6, 115-132. http://dx.doi.org/10.1207/S15327671ESPR0601-2_7

Gutiérrez, R. (2007). (Re)defining equity: The importance of a critical perspective. In N. S. Nasir \& P. Cobb (Eds.), Improving access to mathematics: Diversity and equity in the classroom (pp. 37-50). New York, NY: Teachers College Press.

Gutstein, E. (2003). Teaching and learning mathematics for social justice in an urban, Latino school. Journal for Research in Mathematics Education, 34, 37-73. http://dx.doi.org/10.2307/30034699

Gutstein, E. (2006). Reading and writing the world with mathematics: Toward a pedagogy for social justice. New York, NY: Routledge.

Gutstein, E. (2007). "So one question leads to another": Using mathematics to develop a pedagogy of questioning. In N. S. Nasir \& P. Cobb (Eds.), Improving access to mathematics: Diversity and equity in the classroom (pp. 51-68). New York, NY: Teachers College Press.

Hansen, H. S. (1985). The economics of early childhood education in Minnesota. Journal of Economic Education, 16, 219-224. http://dx.doi.org/10.2307/1182592

Hill, C. H., Schilling, S. G., \& Ball, D. L. (2004). Developing measures of teachers' mathematical knowledge for teaching. Elementary School Journal, 105, 11-30. http://dx.doi.org/10.1086/428763

Huffman, J. B., \& Hipp, K. K. (2003). Reculturing schools as professional learning communities. Lanham, MD: Scarecrow Education.

Husain, D. D., Cahill, J., \& Lozada, M. (1999). A twist on the basics: Lessons in applied learning. Techniques: Making Education \& Career Connections, 74(2), 22-27. Retrieved from ERIC database. (EJ578860)

Kamii, C. (2000). Young children reinvent arithmetic: Implications of Piaget's theory (2nd ed.). New York, NY: Teachers College Press.

Loucks-Horsley, S., Love, N., Stiles, K. E., Mundry, S., \& Hewson, P. W. (2003). Designing professional development for teachers of science and mathematics (2nd ed.). Thousand Oaks: CA: Corwin Press.

Martin, D. B. (2000). Mathematics success and failure among African-American youth: The roles of sociohistorical context, community forces, school influence, and individual agency. Mahwah, NJ: Erlbaum.

Meszaros, B. T., \& Evans, S. (2010). It's never too early: Why economics education in the elementary classroom. Social Studies and the Young Learner, 22(3), 4-7. http://www.socialstudies.org

Moll, L. C., \& Ruiz, R. (2002). The schooling of Latino children. In M. M. Suarez-Orozco \& M. M. Paez (Eds.), Latinos remaking America (pp. 362-372). Cambridge, MA: Harvard University Press.

Morgan, J. C. (1991). Using Econ and Me to teach economics to children in primary grades. The Social Studies, 82, 195-197. http://dx.doi.org/10.1080/00377996.1991.9958336

Posnanski, T. J., Schug, M. C., \& Schmitt, T. (2007). Can students learn economics and personal finance in a specialized elementary school? International Journal of Social Education, 21, 196-205. http://ijse.iweb.bsu.edu/

Skovsmose, O. (1994). Towards a critical mathematics education. Educational Studies in Mathematics, $27,35-57$. http://dx.doi.org/10.1007/BF01284527

Skovsmose, O. (2000). Aporism and critical mathematics education. For the Learning of Mathematics, $20(1), 2-8$. http://www.flm-journal.org

Skovsmose, O., \& Valero, P. (2002). Democratic access to powerful mathematical ideas. In L. D. English (Ed.), Handbook of international research in mathematics education (pp. 383-407). Mahwah, NJ: Erlbaum.

Starratt, R. J. (2004). Ethical leadership. San Francisco, CA: Jossey-Bass.

Tate, W. F. (1995). Race, retrenchment, and the reform of school mathematics. Phi Delta Kappan, 75, 477-485. http://www.kappanmagazine.org

Turner, E. E., \& Strawhun, B. F. (2007). Posing problems that matter: Investigating school overcrowding. Teaching Children Mathematics, 13, 457-463. http://www.nctm.org/publications/toc.aspx?jrnl=tcm 
Vadeboncoeur, J. (2006). Engaging young people: Learning in informal contexts. Review of Research in Education, 30, 239-278. http://dx.doi.org/10.3102/0091732X030001239

Valenzuela, A. (1999). Subtractive schooling: U.S.-Mexican youth and the politics of caring. Albany: State University of New York Press.

Valenzuela, A. (2002). Reflections on the subtractive underpinnings of education research and policy. Journal of Teacher Education, 53, 235-241. http://dx.doi.org/10.1177/0022487102053003007

Walstad, W. B. (1979). Effectiveness of a USMES in-service economic education program for elementary school teachers. Journal of Economic Education, 11, 1-12. http://dx.doi.org/10.2307/1182696

Walstad, W. B., \& Soper, J. C. (1987). Test of Economic Knowledge. New York, NY: Joint Council on Economic Education.

Walstad, W. B., \& Watts, M. (1985). Teaching economics in the schools: A review of survey findings. Journal of Economic Education, 16, 135-146. http://dx.doi.org/10.2307/1182516

Weiss, I. R., \& Pasley, J. D. (2004). What is high-quality instruction? Educational Leadership, 61(5), 24-28. http://www.ascd.org/publications/educational-leadership.aspx

Weiss, I. R., Pasley, J. D., Smith, P. S., Banilower, E. R., \& Heck, D. J (2003). Looking inside the classroom: A study of K-12 mathematics and science education in the United States. Chapel Hill, NC: Horizon Research. http://www.horizon-research.com/insidetheclassroom/reports/looking/ 